\title{
Effectiveness of Guided-Inquiry Model to Train Science Process Skills of Senior High School Students
}

\author{
Arinta Rezty Wijayaningputri ${ }^{1}$, Widodo $^{2}$, Munasir $^{3}$ \\ ${ }^{1}$ Progam Studi Pendidikan Sains, Universitas Negeri Surabaya, Jl. Ketintang, Surabaya 60231, Indonesia \\ Email: rintawijaya84@gmail.com \\ ${ }^{2}$ Progam Studi Pendidikan Sains, Universitas Negeri Surabaya, Jl. Ketintang, Surabaya 60231, Indonesia \\ Email: wahonowidodo@unesa.ac.id \\ ${ }^{3}$ Progam Studi Fisika, Universitas Negeri Surabaya, Jl. Ketintang, Surabaya 60231, Indonesia \\ Email: munasir@unesa.ac.id
}

\begin{abstract}
This research aims to analyze the effectiveness of Guided-Inquiry model to train science process skills. This research design in this study was One-group Pre-test and Post-test which applied to 15 students of senior high school. The data were analyzed using Anova, N-gain and the paired t-test. The result showed that there was a significant improvement of students' science process skill at $\alpha=5 \%$, the average $N$-gain of 1.06 was categorized high. The result of science process skill test before being taught with learning instrument developed had average pretest was 60. The result was low because the ability of the students to understood the material was low and most of the students did not accustomed yet to practice the science process skills, so many students were having trouble. Based on the post-test results of students' science process skills that have increased with an average post-test value of 89 . These results indicated that learning instrument developed through the guided Inquiry model have a positive effect on training students' science process skills. Thus, The Guided-Inquiry Model to train science process skill which was developed is effective.
\end{abstract}

Keywords-Guided-Inquiry; Science Process Skill;
Effectiveness

\section{INTRODUCTION}

The Characteristics of learning in every educational unit closely related to the Graduate Competency Standards and Content Standards. According to Permendikbud No. 22 on the Standard Process of Primary and Secondary Education indicates the need for a learning process guided by scientific or scientific approaches. One of the appropriate lessons is the science lesson.

The nature of the IPA consists of four important points: attitude, process, product, and application. Four important points of these science should appear in the science lesson [1]. To elicit these four important points, the skills of the science process are crucial because the skills of the process of science are the basis of problem solving in science and scientific methods [2]. According to the nature of science, in addition to trained cognitive abilities learning objectives also trained the process of skills. Science learning should provide students with learning experiences in order to develop the skills they possess while also reinforcing the learned material. One of the scientific skills that needs to be trained is the science process skill (SPS). To gain new insights to develop existing insights, each student should have the science process skills in order to apply scientific methods in developing science [3]. In addition, science process skill is a necessary skill to acquire, extend, and apply IPA concepts, principles, laws and theories of intellectual, physical and social skills [4]. In the field of Science, the quality of education in Indonesia is also low. The results of the TIMSS (Trends in International Mathematics and Science Study) survey that measured the scientific inquiry ability showed that the average score of Indonesian students' science achievement in 1999 was 435, making Indonesia in $32 \mathrm{nd}$ from $39^{\text {th }}$ position, 2003 was 37 th of 46th and the average score is 420, as well as the results of 2007 are on the order of 35 out of 49 with an average score of 427 , and the results of the 2011 survey also showed a relatively similar score that is on the order of 39 of 41 with an average score of 406 while the average the international score has already reached 500 [5-8].

The low quality of education can be proven in the results of the Program for International Student Assessment (PISA) study. In 2003 an overview of learning in Indonesia for Literacy of Science and Mathematics, 15-year-olds are ranked $38^{\text {th }}$ out of 40 participating countries [9]. While PISA 2012 Indonesia reached rank $64^{\text {th }}$ of 65 Countries, ranked 38th of $42^{\text {th }}$ in TIMSS 2011 , ranked $40^{\text {th }}$ of $42^{\text {th }}$ at TIMMS 2012, and ranked $41^{\text {th }}$ of $45^{\text {th }}$ in PIRLS 2011 [5-8]. It could also be seen from the results of the pre-research questionnaire in SMA Negeri 1 Pasuruan about KPS obtained that the level of mastery of students on each aspect of science process skills based on the criteria proposed [10] included in the low category with a percentage of $43 \%$. The statement is supported by the data of student learning outcomes that are still low, especially on the material vibration and wave with the average still under the KKM is 75. 
The guided inquiry learning model is a learning model that trains students in finding problems and conducts investigations until they come to the conclusion of the outcome of the problem [1114]. In addition, states the implementation of guided inquiry learning model in the research proved to affect the understanding of the concept of science and science process skills [15]. In addition, the inquiry is built on the understanding that the essence of science learning is that which includes contents, processes and attitudes because through inquiry learning the students are trained to develop the ability to solve $[4,16]$

\section{EXPERIMENTAL METHOD}

\section{A. General Background of Research}

This research is conducted in State Senior High School 1 Pasuruan (SMAN 1 Pasuruan, Indonesia). The research's scope is the senior high school students of $11^{\text {th }}$ grade who took physics subject in school year 2017/2018. The aim was to analysed the effectiveness of Inquiry Teaching Model which analysing the result of students' science process skills on senior high school in physics subject before and after using Inquiry Teaching Model. The effectiveness of Inquiry Teaching Model will be determined based on;1) significant improvement (statistically) on score between pre-test and post-test of students' science process skills on senior high school in physics subject; 2) n-gain average determined at least on low improvement criteria; and 3 ) the existence of score average consistency n-gain students' science process skills on senior high school in physics subject.

\section{B. Sample Research}

The samples of the research were 15 students of State Senior High School 1 of Pasuruan (SMAN 1 Pasuruan, Indonesia) using purposive sampling technique in academic year 2017/2018. Those students have homogeny of science process skills.

\section{Instrumental and Procedures}

The students' science process skills were measured by using Science Process Skills Assessment Sheet which had been declared valid and reliable [17]. Science Process Skills Assessment Sheet were formed based on the measureable science process skills indicator such as: a) Formulating general problems, b) Writing observations, c) Formulating specific problems, d) Formulating hypotheses and predictions, e) Identifying variables, f) Writing operational definitions of variables, g) Writing tools and materials, h) Writing test procedures, i) Organize data of experimental results in the observation table, j) Analysis of experimental data, k) Make a conclusion. [18-21]. The materials of physics subject in this research were chosen according to Inquiry Teaching Model characteristics which are Vibration and Waves. This research used one group pre-test and post-test design, O1 X O2 [18]. The initial learning has started with conducting the pre-test (O1). Every senior high school students are required to work Science Process Skills Assessment Sheet. After the pre-test, the teacher will apply Inquiry Teaching Model and physics learning devices (X). The implementation of Inquiry Teaching Model has been conducted in three meetings on physics subject. Inquiry Teaching Model in learning physics has 6 syntaxes such as: 1) Gain attention and explain inquiry process, 2) Present the inquiry problem of discrepant event. 3) Have students formulate hypotheses to explain the problem or event., 4) Encourage students to collect data to test the hypothesis., 5) Formulate explanations and/or conclusions. And 6) Reflect on the problem situation and the thinking processes used to inquire into it [22]. Learning devices of physics consist of the syllaby, lesson plan, students' work sheet, students' textbooks, teacher's textbooks, Science Process Skills assessment sheet, model observation sheet, students' activity sheet, and questionnaires of respond (valid and reliable) [17]. Every phase of Inquiry Teaching Model were designedly to train the science process skill indicator on physics subject. After the implementation of Inquiry Teaching Model ended by conducting the post-test (O2) using Science Process Skills Assessment Sheet, every student was required to finish Science Process Skills Assessment Sheet on the post-test

\section{Data Analysis}

The students' science process skills on senior high school physics subject was analysed based on a determined assessment before and after using Inquiry Teaching Model. The students' data on science process skills pre-test, post-test and n-gain were analysed advance using inferential statistic with the help of SPSS software (IBM SPSS 24.0). The score of students' science process skills was based on these indicators; : a) Formulating general problems, b) Writing observations, c) Formulating specific problems, d) Formulating hypotheses and predictions, e) Identifying variables f) Writing operational definitions of variables, g) Writing tools and materials, h) Writing test procedures, i ) Organize data of experimental results in the observation table, j) Analysis of experimental data, k) Make a conclusion. [18-21]. N-gain was determined using this equation: $n$-gain $=($ score post-test - score pre-test $) /($ maximum score - pre-test score) [23], with the criteria: (1) if $n$-gain $\geq 7$ (high), (2) if $3<$ n-gain $<7$ (moderate), and (3) if n-gain $\leq 3$ (low). The selection of statistics testing methods depends on the assumptions of normality and the variants homogenety for the score of pre-test, post-test and n-gain students' science process skills. The inferential statistical test is conducted using ShapiroWilk test (analysis about the existence of the improvement statistically) [23].

\section{RESULT AND DISCUSSION}

The Result of pre test and post test of the science process skills are analyzed by quantitative descriptive analysis by calculating the average pre test and post test values, the mean value of pre test and post test are used to calculate the normalized $\mathrm{N}$-gain score. Normalized $\mathrm{N}$-gain scores were used to determine the category of students' science skill between before and after learning using inquiry learning models. The 
result of the research showed on Table. 1, Table. 2, and Table. 3 with the explanation as follows:

TABLE I. THE AVERAGE SCORES OF PRE-TEST, POST-TEST AND NGAIN OF STUDENTS' SCIENCE PROCESS SKILLS ON SENIOR HIGH SCHOOL PHYSICS SUBJECT.

\begin{tabular}{|c|c|c|c|c|}
\hline \multirow{2}{*}{ Numb. } & Pre-test & Post-test & \multirow{2}{*}{ N-Gain } & Category \\
\cline { 2 - 5 } & Score & Score & & \\
\hline 1. & 20 & 75 & 0,69 & High \\
\hline 2. & 30 & 95 & 0,93 & High \\
\hline 3. & 40 & 90 & 0,83 & High \\
\hline 4. & 20 & 90 & 0,88 & High \\
\hline 5. & 30 & 80 & 0,71 & High \\
\hline 6. & 40 & 100 & 1,00 & High \\
\hline 7. & 20 & 80 & 0,75 & High \\
\hline 8. & 30 & 80 & 0,71 & High \\
\hline 9. & 40 & 100 & 1,00 & High \\
\hline 10. & 20 & 75 & 0,69 & High \\
\hline 11. & 30 & 90 & 0,86 & High \\
\hline 12. & 50 & 95 & 0,90 & High \\
\hline 13. & 50 & 95 & 0,90 & High \\
\hline 14. & 60 & 100 & 1,00 & High \\
\hline 15. & 60 & 90 & 0,75 & High \\
\hline Average & 36 & 89 & 0,84 & High \\
\hline
\end{tabular}

Table 1 showed the average score of pre-test, post-test and n-gain of students' science process skills on senior high school physics subject. The entire group showed the pre-test average score was 36 (under criteria). This data is emerged because the students still had much difficulties and unfamiliar ideas to implement the science process skill in physics. Those finding was suitable with the result of the early study conducted by the researchers that students' science process skills is still below the standard. In contrary with the post-test's score after implementing Inquiry Teaching Model, in all group the data was 89 . all of them were in high category which shown in the Table 1 shows that n-gain students' science process skills on senior high school physics subject score was 0.84 in high category. The result of this research has proven that the implementation of Inquiry Teaching Model was effectively proven to train students' science process skills on senior high school physics subject. This is existed because Inquiry Teaching Model has been developed to fulfil the validity (content and construction), practicality and effectivity to improve students' science process skills on senior high school physics [24]. This is also supported by the research result [24] that the teaching model has been declared feasible by fulfilling the validity (content and construct), practicality and effectiveness will be able to improve and achieve the aim of the learning.
TABLE II. THE AVERAGE SCORES OF PRE-TEST, POST-TEST AND NGAIN OF STUDENTS' SCIENCE PROCESS SKILLS ON SENIOR HIGH SCHOOL PHYSICS SUBJECT.

\begin{tabular}{|c|c|c|c|c|c|}
\hline Numb. & Indicator & $\begin{array}{l}\text { Pre- } \\
\text { Test }\end{array}$ & $\begin{array}{c}\text { Post- } \\
\text { Test }\end{array}$ & $\begin{array}{c}\mathrm{N}- \\
\text { Gain }\end{array}$ & Category \\
\hline 1 & $\begin{array}{c}\text { Formulating } \\
\text { general } \\
\text { problem }\end{array}$ & 60.00 & 86,67 & 0,30 & Medium \\
\hline 2 & $\begin{array}{c}\text { Write } \\
\text { observation }\end{array}$ & 26,67 & 73,33 & 0,38 & Medium \\
\hline 3 & $\begin{array}{c}\text { Formulating } \\
\text { spesific } \\
\text { problem } \\
\end{array}$ & 26,67 & 73,33 & 0,38 & Medium \\
\hline 4 & $\begin{array}{l}\text { Formulating } \\
\text { hypothesis } \\
\text { and } \\
\text { prediction }\end{array}$ & 33,33 & 73,33 & 0,34 & Medium \\
\hline 5 & $\begin{array}{c}\text { Identifying } \\
\text { variables }\end{array}$ & 46,67 & 80,00 & 0,32 & Medium \\
\hline 6 & $\begin{array}{c}\text { Writing } \\
\text { operational } \\
\text { definitions of } \\
\text { variables }\end{array}$ & 33,33 & 86,67 & 0,46 & Medium \\
\hline 7 & $\begin{array}{l}\text { Writing tools } \\
\text { and materials }\end{array}$ & 40,00 & 93,33 & 0,48 & Medium \\
\hline 8 & $\begin{array}{l}\text { Writing test } \\
\text { procedures }\end{array}$ & 33,33 & 80,00 & 0,40 & Medium \\
\hline 9 & $\begin{array}{c}\text { Organize } \\
\text { data of } \\
\text { experimental } \\
\text { results in the } \\
\text { observation } \\
\text { table } \\
\end{array}$ & 26,67 & 73,33 & 0,38 & Medium \\
\hline 10 & $\begin{array}{c}\text { Make a } \\
\text { conclusion }\end{array}$ & 26,67 & 73,33 & 0,38 & Medium \\
\hline \multicolumn{2}{|c|}{ Average } & 32,59 & 79,33 & $\mathbf{0 , 3 8}$ & Medium \\
\hline
\end{tabular}

Table 2 showed that all of student's science process skills indicators on pre-test were on the low category, whereas after the implementation of physics learning with Inquiry Teaching Model, it showed that all of the indicator of student's science process skills has improved. The general n-gain student's science process skills indicator was on the medium category with the score was 0.38 . The positive result is existed because the implementation of physics learning with Inquiry Teaching Model has been improved the student's science process skills indicator consisting of: a) Formulating general problems, b) Writing observations, c) Formulating specific problems, d) Formulating hypotheses and predictions, e) Identifying variables f) Writing operational definitions of variables, $g$ ) Writing tools and materials, h) Writing test procedures, i ) Organize data of experimental results in the observation table, j) Analysis of experimental data, k) Make a conclusion and analysing through six phases of Inquiry Teaching Model such as: 1) Gain attention and explain inquiry process, 2) Present the inquiry problem of discrepant event.3) Have students formulate 
hypotheses to explain the problem or event., 4) Encourage students to collect data to test the hypothesis., 5) Formulate explanations and/or conclusions. And 6) Reflect on the problem situation and the thinking processes used to inquire into it [22]. The prior researchers has also explained that the Guided Inquiry has an effect on students' science process skills [25]. The result of normality test and homogeneity variants has informed that the score of pre-test, post-test and n-gain student's science process skills on senior high school physics subject is homogeny and abnormally distributed for the whole group.

TABLE 3. THE RESULT OF WILCOXON TEST AND KRUSKALWALLI'S TEST. THE RESULT OF NORMALITY TEST, HOMOGENEITY TEST, AND PAIRED T-TEST IS SHOWN IN TABLE 3.

\begin{tabular}{|c|c|c|c|c|c|c|c|c|}
\hline \multirow[b]{2}{*}{ Sample } & \multirow[b]{2}{*}{$\alpha$} & \multicolumn{2}{|c|}{ Normality test } & \multicolumn{2}{|c|}{ Homogenity test } & \multicolumn{3}{|c|}{ Paired T-Test } \\
\hline & & Sig & $\begin{array}{c}\text { Categ } \\
\text { ory }\end{array}$ & Sig & Category & $\mathrm{t}$ & df & $\begin{array}{c}\text { Sig } \\
(2- \\
\text { tailed })\end{array}$ \\
\hline $\begin{array}{c}15 \\
\text { students } \\
\text { of Class } \\
\text { XI IPA } \\
3 \\
\end{array}$ & 0.05 & 0.725 & $\begin{array}{c}\text { Norm } \\
\text { al }\end{array}$ & 0.174 & homogen & -19.897 & 14 & 0.000 \\
\hline
\end{tabular}

Table. 3 showed The results of normality test using Shapiro Wilk test is shown in Table 1 . Based on testing hypothesis $\mathrm{H}_{0}$ and $\mathrm{H}_{\mathrm{a}}$, sig $>\alpha$ then $\mathrm{H}_{0}$ is accepted, it means that the data came from normally distributed population. It means that the condition of the sample taken is similar to the actual population. The result of homogeneity test using Shapiro Wilk test is shown in Table 1. Based on hypothesis test of $\mathrm{H}_{0}$ and $\mathrm{H}_{\mathrm{a}}$, sig $>\alpha$ then $\mathrm{H}_{0}$ is accepted, it means the data comes from homogeneous population variance. It shows that all students have the same knowledge ability at the beginning of learning. The result of paired t test is shown in Table 1. Based on testing hypothesis $\mathrm{H}_{0}$ and $\mathrm{H}_{\mathrm{a}}$, sig $<\alpha$ then $\mathrm{H}_{0}$ is rejected or $\mathrm{t}_{\text {table }}<\mathrm{t}_{\text {count }}$, then $\mathrm{H}_{0}$ is rejected, meaning that there is significant difference in pre test result and post test result. It shows shows inquiry model gives affect to result of pre test and post test of science process skill of student.

\section{CONCLUSION}

Inquiry Teaching Model is a specific model which developed to train students' science process skill of students in senior high school. This model has six syntaxes: 1) Gain attention and explain inquiry process, 2) Present the inquiry problem of discrepant event. 3) Have students formulate hypotheses to explain the problem or event., 4) Encourage students to collect data to test the hypothesis., 5) Formulate explanations and/orconclusions. And 6) Reflect on the problem situation and the thinking processes used to inquire into it.. The results of the study prove that: 1) There is an improvement in critical thinking skills at $\alpha=5 \% ; 2$ ) Average score of n-gain science process skills of high school students' 0.84 (high category). Therefore, Inquiry Teaching Model has been proven to be effective to train students' science process skills on senior high school physics subjects. The implications of this research are an alternative to train students' science process skills through physics-based Inquiry learning.

\section{ACKNOWLEDGMENT}

The author thanked to the Surabaya State University, principal and physics teacher of State Senior High School 1 of Pasuruan who has supported and assisted the research.

\section{REFERENCES}

[1] G. Eason, B. Noble, and I.N. Sneddon, "On certain integrals of LipschitzHankel type involving products of Bessel functions," Phil. Trans. Roy. Soc. London, vol. A247, pp. 529-551, April 1955. (references)

[2] J. Clerk Maxwell, A Treatise on Electricity and Magnetism, 3rd ed., vol. 2. Oxford: Clarendon, 1892, pp.68-73.

[3] I.S. Jacobs and C.P. Bean, "Fine particles, thin films and exchange anisotropy," in Magnetism, vol. III, G.T. Rado and H. Suhl, Eds. New York: Academic, 1963, pp. 271-350.

[4] K. Elissa, "Title of paper if known," unpublished.

[5] R. Nicole, "Title of paper with only first word capitalized," J. Name Stand. Abbrev., in press.

[6] Y. Yorozu, M. Hirano, K. Oka, and Y. Tagawa, "Electron spectroscopy studies on magneto-optical media and plastic substrate interface," IEEE Transl. J. Magn. Japan, vol. 2, pp. 740-741, August 1987 [Digests 9th Annual Conf. Magnetics Japan, p. 301, 1982].

[7] M. Young, The Technical Writer's Handbook. Mill Valley, CA: University Science, 1989.

[8] Kementerian Pendidikan dan Kebudayaan, Peraturan menteri Pendidikan dan Kebudayaan No. 58 Tahun 2014 tentang panduan penilaian untuk SMA/MA, Jakarta: Kemendikbud, 2014.

[9] I. A. S.Wilujeng, and Liliasari, "Kompetensi IPA Terintegrasi Melalui Pendekatan Keterampilan Proses Mahasiswa S-1 Pendidikan IPA," Jurnal Cakrawala Pendidikan November 2010, Th.XXIX, No. 3. Yogyakarta. 14 2010

[10] Nworgu and Otum, Journal of Education and Practice, vol. 27 pp 35-40 2013

[11] N Y Rustaman, Perkembangan Penelitian Pembelajaran Berbasis Inkuiri Dalam Pendidikan Sains, Bandung: Universitas Pendidikan Indonesia, 2005

[12] Y Yuliati, "Peningkatan Keterampilan Proses Sains Siswa Sekolah Dasar Melalui Model Pembelajaran Berbasis Masalah,” Jurnal Cakrawala Pendas. Vol. 2 No. 2, 2002

[13] OECD, PISA 2012 results, Washington: OECD Publishing, 2014

[14] OECD, PISA 2015, Washington: OECD Publishing, 2015

[15] OECD, PISA 2015 result in focus, Washington: OECD Publishing, 2016

[16] A. Tjalla, Potret Mutu Pendidikan Indonesia Ditinjau dari Hasil-Hasil Studi Internasional, http://pustaka.ut.ac.id/pdfartikel/TIG601.pdf, 2009

[17] S. Muhibbin, Psikologi Pendidikan dengan pendekatan baru, Bandung:PT Remaja Rosdakarya, 2010

[18] C J Wenning, "Levels of inquiry: Levels of inquiry: Hierarchies of pedagogical practices and inquiry processes", Journal of Physics Teacher Education Online, vol. 2 no.3, Illinois State University Physics Dept, 2005

[19] C J Wenning \& R Wenning, "Generic Model For Inquiry - Oriented Labs In Post Secondary Introductory Physics,” Journal of Physics Teacher Education Online, vol. 2 no. 3, Illinois State University Physics Dept, 2006 A.

[20] C. J. Wenning, "Assessing inquiry skills as a component of scientific literacy," Journal of Physics Teacher Education Online, vol. 5 no.4, Illinois State University Physics Dept, 2007. 
[21] C. J. Wenning, "Levels of inquiry: Using inquiry spectrum learning sequences to teach science," Journal of Physics Teacher Education Online, vol. 4 no. 2, Illinois State University Physics Dept, 2010.

[22] R Darwis. \& N Rustaman, "Pembelajaran Berbasis Inkuiri dengan Aktivitas Laboratorium untuk Meningkatkan Keterampilan Proses Sains Siswa SMP," Jurnal Pendidikan IPA Indonesia, vol. 4, no.1 pp.46-50, 2015.

[23] A. R. Wijayaningputri, Pengembangan Perangkat Pembelajaran Berbasis Inkuiri Terbimbing untuk Melatihkan Keterampilan Proses Sains Siswa, Surabaya: Pascasarjana Unesa, 2018.

[24] K. Sevilay, Analysis of Turkish High School Chemistry Examination Question According to Bloom's taxonomy, In Chemistry 136 Edication: Recearch and Practice [Online], Vol 4, no 1, pp. 25-30, 2003. http://www.uoi.gr/accessed on 24 April 2018.
[25] M. N. Sheeba, "An Anatomy of Science Process Skills in The Light of the Challenges to Realize Science Instruction Leading to Global Excellence in Education," Educationia Confab Journals.Vol. 2, No. 4. 108-123, 2013.

[26] M. Nur, Modul Keterampilan-Keterampilan Proses Sains, Surabaya : Pusat Sains dan Matematika Sekolah Universitas Negeri Surabaya, 2011c.

[27] Sugiyono, Metode Penelitian Pendidikan (Pendekatan Kuantitatif, Kualitatif dan R\&D), Bandung: Alfabeta, 2014.

[28] R. I. Arends, Belajar Untuk Mengajar (Learning to teach), Jakarta : Salemba Humanika, 2013.

[29] R. R. Hake, Am. J. Phys. 1998.

[30] P. Griffin and E. Care, Assessment and teaching of 21st century skills New York: Springer, 2015.

[31] Nworgu and Otum, Effect of Guided Inquiry with Analogy Instructional Strategy on Students Acquisition of Science Process Skills. Journal of Education and Practice. vol 27, no.4, pp.35-40, 2013. 